\title{
Generation of an Instrument Base for Analysis of Economic Processes for the Purpose of Building a Model of Spatial Development of Regions in the Context of Global Challenges
}

\author{
Tatiana Kolesnikova ${ }^{1}$, Liudmila Smolennikova ${ }^{1 *}$, Natalia Strelnikova ${ }^{1}$ and Sofia Sultanova $^{2}$ \\ ${ }^{1}$ Volga State University of Technology, 424000, Yoshkar-Ola, Russia \\ ${ }^{2}$ Tashkent State Transport University, Tashkent, Uzbekistan
}

\begin{abstract}
The article considers the issues of generation of an instrument base for analysis of the economic processes at the meso-level. Based on the official statistic reporting (big data) we establish a set of indicative figures that describe the results of socioeconomic development and help to determine a production profile of a region and priorities for investments in purpose of ensuring a spatial development of the territories based on the principles of economic stability.
\end{abstract}

\section{Introduction}

The economic stability of the Russian Federation is ensured by balanced, integrated and systematic development of its subjects, effective performance of the regions. A region's participation in the building-up of the economic potential of the country as well as its economic advantages and competitive opportunities are mainly determined by the environmental and dynamic characteristics of the socioeconomic system of the region, organization and structural features of its economy, in particular, by the presence and diversification of the industrial production, the agricultural sector, the power-generating sector, their effective performance and investment activity. In addition, it is influenced by transportation accessibility, availability of raw materials and qualified human resources. Specialization of the regional economy based on the optimal use of available production and natural resources, human capital assets helps to ensure a progressive growth of a region and achieve additional effects from investments into the economy.

In the context of creating preconditions for accelerated technological development and digitalization of the economy, the analysis of the economic processes at the meso-level as a base for justification of priorities and objectives of the regional development with regard to risks, threats and dampers becomes especially relevant.

\footnotetext{
*Corresponding author: SmolennikovaLV@volgatech.net
} 


\section{Materials and methods}

The goal of this study is to generate an instrument base for analysis of the economic processes at the meso-level for the purposes of determination of regional production specialization and investment priorities aiming at spatial development of territories on the base of the economic stability principles.

The main object of the study is the results of the socioeconomic development of the regions and the key sectors of the regional economy as well as the destructive factors and threats of the regional development.

The methodological framework of the study is comprised of the provisions of a systemsynergetic approach on a dialectic basis, that are applied to the study of the economic processes of a region as a dynamically developing system. This study uses formal logical and general scientific methods which ensure a necessary depth of analyzing the main aspects of the research problem: they are abstract logical, monographic methods, deduction, induction, synthesis, classification, an economic statistical method, economic simulation, construction of an integral indicator, an expert method, a calculation-constructive method. The issues of economic stability was studied by many researchers including L.I. Abalkin, M.A. Azarskaia, M.A. Bendikov, S.Iu. Glazev, A.P. Gradov, I.V. Ilin, E.A. Iliashenko, A.V. Kalina, V.V. Krivorotov, G.B. Kleiner, I.K. Larionov, O.A. Mironova, E.A. Oleinikov, V.L. Ortynskii, V.L. Pozdeev, V.K. Senchagov, V.L. Tambovtsev, A.I. Tatarkin, V.Kh. TSukanov, and others. However, the current context of the economy functioning, new challenges and threats at all the levels of the economic system dictate a necessity to further investigate the issue of justifying the priorities of regional development based on the economic stability principles and the relevance of generating an instrument base for analysis of the spatial economy.

\section{Experimental part}

The development of any state is based on solving the problems of national security what helps to preserve the national sovereignty and territorial integrity as well as a possibility to adequately response to external and internal dangers and threats. An essential component of the national security is the economic stability that ensures quality standard of living, socioeconomic and political stability.

According to the National Security Strategy of the Russian Federation approved by the RF President's Decree No.683 of December 31, 2015, the main strategic threats to the economy include its low competitiveness, a lag in development and implementation of advanced technologies, an uneven growth of regions. The urgent objective is a balanced, integral and systemic development of the regions, an accelerated development of the innovative sectors of the economy, a rise of the level of the technological development, investment attractiveness of the economic subjects and intensification of the investment processes. The Spatial Development Strategy of the Russian Federation till 2025 approved by Resolution of the Government of the Russian Federation No.207-p of February 13, 2019 states the key objectives including ensuring the national security through the socioeconomic development of the territories and improving the competitiveness of the economies of the RF subjects (by means of implementing conditions for development of productions in the sectors of promising economic specializations). Therefore, enhancing the role of the regions is a focus of the economic and political life of the country, and the analysis and justification of the priorities in their development with regard to risks, threats and dampers become especially important in the context of creating preconditions for accelerated technological development and digitalization of the economic processes what determines a necessity of building an instrumental base for analysis of the economic processes at the meso-level. 
Generalization of the described in the scientific literature approaches to the essential characteristics of the economic stability [1-3] reveals the following:

- the economic stability of an object of any level means security of its economy from any external or internal threats when a sustainable growth of the economy and socially oriented development, meeting the state, society, personal needs are ensured based on the effective use of resources;

- the economic stability is based on the effective use of the economic potential of the territory, appropriate elimination of threats and control of the risks to the economic activity[4].

The theoretic and methodological studies of the economic stability suggest a conclusion about socio-legal congruency of the essential definition of the state economic stability and regional economic stability: the main characteristics including the essence, principles, criteria, factors, threats, etc. are similar, though represented in the different scales. In this connection, under the economic stability of a region we understand a state of its economy when based on the functioning of the regional management system and the effective use of the economic potential (the natural, labor, material, and financial resources of a region) a security from exposure to the destructive factors, a possibility to adjust to the changes in the external environment and as a consequence a sustainable growth and socially oriented development are ensured [4]. We can state the key meso-level principles of ensuring the economic stability: a focus on maintaining the sustainable growth rates in the economic system of a region; an ability to implement own projects, implementation of own decisions aimed at stabilization of the economy; maintaining the stability of the labor resources and the employment level with reference to the regional needs; maintaining a decent standard of living of the population; consistency of the security from risks and threats.

When building up the territorial proportions of the regional economic development based on these principles, we need to make a comparative analysis of its industries. In this context, the comparison may be made using one indicator taken as a priority (e.g. an impact on the gross regional product value of the product volume manufactured by the different industries) or using a set of synthetic (summary) indicators. The quantitative characteristics can be added with the qualitative one which suggests analysis of the regional mechanism regulating the investment activity and of the support to investors [5].

For the purposes of determination of the production specialization of a region, based on the hypothesis of the relationships between the Gross Regional Product (GRP, which is an effective feature) and the performance of the industries within the regional economy (a production volume) (these two are considered as factors) we make a correlation-regression analysis of the impact made by the factorial features on GRP. This analysis reveals the key industries of the economy, which generate the Gross Regional Product. Thus, for instance, based on the investigation of the performance of the economic sectors in the Republic of Mari El (Table 1) we can make a conclusion on a close linear correlation relationship between the analyzed values (the multiple correlation coefficient $\mathrm{R}=0.9997$ ), i.e. a strong dependency of the GRP value on the production volumes in the predetermined sectors of the economy: industry, transport and communications, agriculture, commerce, construction. At the same time, the GRP value varies mostly under the influence of the industrial production and agriculture (the highest correlation coefficient). The region has an industrial and agricultural specialization. 
Table 1. Trend data of the regional economy sectors and GRP, million Rubles.

\begin{tabular}{|c|c|c|c|c|c|c|}
\hline Year & $\begin{array}{c}\text { GRP, } \\
\text { Y }\end{array}$ & $\begin{array}{c}\text { Industrial } \\
\text { production } \\
\text { volume, } \\
\mathbf{X 1}\end{array}$ & $\begin{array}{c}\text { Agricultural } \\
\text { production } \\
\text { volume, } \\
\mathbf{X 2}\end{array}$ & $\begin{array}{c}\text { Freight } \\
\text { transport } \\
\text { ation } \\
\text { volume, } \\
\mathbf{X 3}\end{array}$ & $\begin{array}{c}\text { Construction } \\
\text { work volume, } \\
\mathbf{X 4}\end{array}$ & $\begin{array}{c}\text { Retail } \\
\text { trade } \\
\text { volume, } \\
\mathbf{X 5}\end{array}$ \\
\hline 2000 & $11,207.6$ & 65,188 & $5,021.2$ & 866.6 & $1,066.7$ & $5,174.7$ \\
\hline 2004 & $33,350.7$ & 133,723 & $8,306.2$ & 936.9 & $2,626.7$ & $10,787.3$ \\
\hline 2008 & $65,765.3$ & 193,250 & $16,863.2$ & $1,445.7$ & $9,962.2$ & $36,189.2$ \\
\hline 2012 & $117,201.1$ & 286,499 & $25,194.4$ & $2,321.3$ & $12,353.0$ & $56,068.3$ \\
\hline 2016 & $158,716.7$ & 404,552 & $43,545.6$ & $1,187.0$ & $13,214.7$ & $78,497.6$ \\
\hline 2017 & $169,478.5$ & 418,477 & $38,883.9$ & $1,225.0$ & $13,739.7$ & $81,990.7$ \\
\hline 2018 & $178,928.0$ & 470,091 & $41,386.4$ & $1,265.5$ & $15,204.6$ & $86,591.6$ \\
\hline
\end{tabular}

To define the sectors of the regional economy that can be priorities for investments and to generate a strategy of the regional development, we use a ranking score method based on a set of indicators representing the sector contribution into the development of the region. An information base for assessment is a statistic database compiled on the uniform methodological principles that ensures comparability of the sector characteristics and helps to build rankings of the different aspects of activity within the sectors.

Considering the official statistic reporting, we can state the following synthetic indicators of the sector assessment for the purposes of establishing priorities for investments:

1) a potential of the sector development (a productive capacity of the sector) $\left(K_{p}\right)$ defined based on the analytical indicators representing a business activity of the sector and characterizing the sector's impact degree on the GRP generation and a potential need in investments. These indicators include a production index, a sector share in the added value, an index of the actual volume of the gross added value, a sector share in the shipped product volume, a sector share in the total value of the fixed assets, a coefficient of renewal of the fixed assets, a degree of depreciation of the fixed assets, a proportion of the operated fixed assets, a level of use of the average annual productive capacity (for the industrial production);

2) financial performance and solvency $\left(K_{f}\right)$ defined based on the analytical indicators characterizing the efficiency of the economic activity of enterprises and the sector as a whole. These indicators include a proportion of loss-makers of the sector, a profitability of sales, a profit margin (a profitability of goods and assets), a bank-liquidity ratio, an equity ratio, a working capital to current assets ratio, a proportion of overdue accounts payable, a proportion of overdue accounts receivable;

3 ) investment activity $\left(K_{i n v}\right)$ defined based on the analytical indicators representing an investment climate generated in the region as well as the pursuance of production renewal, retooling. These indicators include a share of the sector in the investments into the capital assets, a growth rate of the investments into the capital assets (an index of the physical volume of the investments into the capital assets), a cost efficiency factor of the investments, a proportion of the sector companies making investments, a leverage ratio of the financial sources of investments;

4) a labor potential (social significance) $\left(K_{l}\right)$ defined based on the analytical indicators characterizing the attractiveness of the production for employees, a workforce stability. These indicators include a sector employment rate (a sector share of average annual number of employed persons in the regional average annual number of employed persons), a sector employment rate of human resources having higher education and vocational secondary 
education, a correlation of the average monthly nominal accrued wage of the sector employees and the average regional value of the same.

In order to transform the absolute values of the indicators in the relative ones and further to define the ranking values, we can take the indictors of the certain sector (e.g. agriculture) as a base.

We make an integrated quantitative assessment of the sectors of the regional economy using an integral ratio of the ranking score $(\mathrm{Kr})$ :

$$
\mathrm{Kr}=\sum \mathrm{K}_{\mathrm{i}} / 4
$$

where $K_{i}$ is a ranking indicator of the considered element of the sector assessment.

During the assessment, similarly to the assessment procedure of the sector attractiveness, we can take into account different degrees of significance of the individual indicators for making investment decisions, such degree is determined by expertise. Based on the approach suggested by I.A. Blank (2004) [6], we propose the following significance of the individual elements for calculations of the integral ranking indicator of the sector:

- a potential level of the sector development - $20 \%$ (the indicators of the sector production potential, the indicators of the sector labor potential);

- an efficiency level of the sector - 65\% (the indicators of financial performance and solvency of the sector enterprises);

- a sector level of investments risks - 15\% (the indicators of the sector investment activity).

In this case the integral ratio of the ranking score is calculated according to the following formula:

$$
\mathrm{Kr}=\sum \mathrm{K}_{\mathrm{i}}^{*} \mathrm{ES}_{\mathrm{i}}
$$

where $K_{\mathrm{i}}$ is a ranking indicator of the considered element of the sector assessment, $\mathrm{ES}_{\mathrm{i}}$ is a significance of the relevant element in the total score of the sector.

Table 2. The indicators of the ranking score of the investment priorities among the sectors of the

\begin{tabular}{|c|c|c|c|c|c|c|}
\hline \multirow[b]{2}{*}{ Indicators } & \multirow[b]{2}{*}{$\begin{array}{l}\text { Agricult } \\
\text { ure } \\
\text { (base) }\end{array}$} & \multicolumn{2}{|c|}{ Industry } & \multirow[b]{2}{*}{$\begin{array}{c}\text { Constru } \\
\text { ction }\end{array}$} & \multirow[b]{2}{*}{$\begin{array}{c}\text { Transpo } \\
\text { rt and } \\
\text { commun } \\
\text { ications }\end{array}$} & \multirow[b]{2}{*}{$\begin{array}{c}\text { Commer } \\
\text { ce }\end{array}$} \\
\hline & & $\begin{array}{c}\text { Processi } \\
\text { ng } \\
\text { producti } \\
\text { on }\end{array}$ & $\begin{array}{c}\text { Energy, } \\
\text { gas, } \\
\text { water } \\
\text { supply }\end{array}$ & & & \\
\hline $\mathrm{K}_{\mathrm{p}}$ & 8 & 15.48 & 5.3 & 5.77 & 5.78 & 10.54 \\
\hline$K_{f}$ & 8 & 20.31 & 8.74 & 5.24 & 12.2 & -11.42 \\
\hline$K_{i n v}$ & 2 & 3.87 & 1,12 & 0.7 & 0.28 & 0.85 \\
\hline$K_{1}$ & 3 & 4.78 & 3.12 & 2.99 & 3.42 & 3.87 \\
\hline $\begin{array}{l}\text { Integral } \\
\text { ranking } \\
\text { indicator }\end{array}$ & 7.7 & 17.8 & 7.5 & 5.3 & 9.8 & -4.4 \\
\hline
\end{tabular}
regional economy (the case of the Republic of Mari El).

Based on the made calculations we range the sectors (Table 2)from the point of view of their attractiveness for investments and selection of strategic priorities of the economy development aimed at ensuring the economic growth and the region stability. The highest score in the Republic of Mari El belongs to the industry (the processing productions), transport and communications, agriculture. The further and deeper analysis is made by the types of the economic activity within the sector having the highest score of the investment priority. For the Republic of Mari El, it is the processing productions. 
The official statistic data make it possible to use the following as the indicators:

- a number of operating organizations; a volume of shipped products, a share of the shipped product volume by the types of the economic activity in the total volume of the shipped products of the processing productions; a production index; a share of fixed assets in the total value of the fixed assets of the processing productions; a level of use of the average annual productive capacity; a degree of depreciation of the fixed assets;

- a balanced financial result; a proportion of the profitable companies; a profitability of sales; a return on the assets;

- investments into the capital assets; a share of investments into the capital assets in the total volume of the regional investments;

- a proportion of the employee number in the total employee number in the regional economy; a correlation of the average monthly nominal accrued wage of the employees and the average regional value of the same; producer price indexes.

Based on the analysis of the data trends in the different types of the economic activity we generate a matrix revealing comparative advantages of the investigated types of the economic activity. Thus, for the Republic of Mari El it is found that comparative advantages belong to food production, timber processing and woodwork production, manufacture of paper and paper products, printing production, manufacture of finished metal products, machines and equipment, electrical equipment, motor vehicles. These types of the economic activity are so-called points of growth, the concentration of funds in which may ensure the greatest multiplying effect for the regional economy.

The results of this study in part of identifying the priority spheres (sectors) for investments can make the established by the RF Spatial Development Strategy - 2025 effective economic specializations of the subjects of the Russian Federation more specific. Thus, for the Republic of Mari El such types of activity as manufacture of textile products, non-metal mineral products, computers, electronic and optical products, furniture, clothing have a relatively low level of advantages and may not be considered as priorities for investments despite their listing in the Strategy.

\section{Conclusion}

The comparative advantages of the economy sectors and the individual types of activity form a regional production specialization being a basis for the economic development of the territory.

The proposed instruments help to define a production specialization as well as a list of priorities for investments into the sectors of the regional economy and the types of activities for justifying the prospects of the regional development and attaining the sustainable development goals on the basis of the economic stability principles.

\section{References}

1. C.Yu. Glazyev, Russian Economic Journal, 1, pp. 3-16 (1997)

2. V.Kh. Tsukanov, Economic security: essence, factors of influence and methods of support (Chelyabinsk House of Press, Chelyabinsk, 2007)

3. V.L. Pozdeev, Innovative development of the economy, 6, pp. 277-287 (2016)

4. L.V. Smolennikova, Innovative development of the economy, 4-5, pp. 284-293 (2020)

5. L.V. Smolennikova, T.G. Kolesnikova, Innovative development of the economy, 3, pp. 176-186 (2020)

6. I.A. Blank, Fundamentals of Investment Management (Elga: Nika-Center, Kiev, 2004) 